\title{
Safety, pharmacokinetics, relative bioavailability and dose linearity of four formulations of emodepside in healthy male subjects
}

\author{
Jean-Yves Gillon ${ }^{1}$, Jeremy Dennison ${ }^{2}$, Frans Van Den Berg ${ }^{2}$, Sophie Delhomme ${ }^{1}$, Karen \\ Dequatre-Cheeseman ${ }^{1}$, Claudia Peña-Rossi ${ }^{1}$, Natalie Strub-Wourgaft ${ }^{1}$, Sabine Specht ${ }^{1}$, \\ Belen Pedrique ${ }^{1}$, Frederic Monnot ${ }^{1}$, Susanne Skrabs ${ }^{3}$, Maria-Luisa Rodriguez ${ }^{3}$, and Heino \\ Stass $^{3}$ \\ ${ }^{1}$ Drugs for Neglected Diseases initiative \\ ${ }^{2}$ Hammersmith Medicines Research Ltd \\ ${ }^{3}$ Bayer AG
}

August 28, 2020

\begin{abstract}
Aims: Emodepside is an anthelmintic, originally developed for veterinary use. We investigated the safety, pharmacokinetics, relative bioavailability and dose linearity of four oral formulations of emodepside in healthy male subjects. Methods: Three randomised, parallel-group, controlled, Phase I studies were conducted using various oral formulations, involving 79 subjects in ten cohorts in the single-ascending-dose study, 24 subjects in three ascending-dose cohorts in the multiple-ascending-dose study and 77 subjects in seven different cohorts in the relative bioavailability study. Pharmacokinetics and safety assessments were performed up to 21, 30 and 7 days, respectively. Results: As a liquid service formulation, emodepside was rapidly absorbed under fasting conditions, with dose-proportional increases in plasma concentrations at doses from $1 \mathrm{mg}$ to $40 \mathrm{mg}$. The half-life during the first 24 hours after dosing was around 11 hours, followed by a terminal elimination half-life $>500$ hours. Emodepside was less bioavailable in the fed state. The rate of absorption was slower and Cmax was lower with the amorphous solid dispersion tablets compared to the liquid service formulation. Emodepside was well tolerated overall with no major safety concerns. Conclusion: These Phase I studies with various dosage forms revealed a pharmacokinetic profile suggesting good tissue distribution of emodepside and a long terminal half-life. A $15 \mathrm{mg}$ dose with the gastrosoluble tablet is predicted to provide exposure that will achieve the target concentration for clinical efficacy. These data enabled us to select a field-adapted tablet formulation that will open the way for further clinical development of emodepside in individuals with onchocerchiasis.
\end{abstract}

\section{Clinical Trial Registration:}

NCT02661178, NCT03383614 and NCT03383523 (clinicaltrials.gov)

\section{d) Main text}

\section{Introduction}

Onchocerciasis ("river blindness") is a neglected tropical disease caused by Onchocerca volvulus, a parasitic nematode transmitted to humans through the bite of the blackfly. ${ }^{1}$ The larvae mature into reproductively competent adults within 1 year. Adult worms have a lifespan of 9-11 years and reside primarily in subcutaneous and deep-tissue nodules where they produce progeny (microfilariae). The disease results from the death of the microfilariae, which prompts an inflammatory response, causing skin rash and lesions, including skin depigmentation, and unbearable itching. Microfilariae also migrate to the eye, causing local inflammation and other complications, including eye lesions, often leading to blindness. ${ }^{2}$ Onchocerciasis is endemic in 27 countries mainly in sub-Saharan Africa, as well as in Yemen and Latin America. ${ }^{1}$ 
Onchocerciasis treatment and control currently rely on mass drug administration (MDA) of ivermectin (Mectizan ${ }^{\circledR}$, Merck \& Co. Inc.) ${ }^{3}$ which targets the microfilarial stage of the parasite and temporarily sterilises, but does not kill, the adult worms. MDA programmes must therefore be repeated at regular intervals for many years, which represents a considerable economic and logistical burden in endemic countries. There is also mounting evidence of potential resistance to ivermectin. ${ }^{4}$ Another avermectin parasiticide, moxidectin, was approved in 2018. Like ivermectin, it targets only microfilariae. ${ }^{5}$

Thus, there is an urgent need for new agents against onchocerciasis. Ideally, such agents should have activity against multiple life-stages of the parasite, a good safety profile and a long-lasting effect with a relatively simple dosing regimen.

Emodepside, a semi-synthetic cyclo-octadepsipeptide, is active across multiple nematode species. ${ }^{6}$ Like ivermectin and moxidectin, ${ }^{7,8}$ emodepside was originally developed as an anthelmintic for veterinary use. It was first marketed as Profender ${ }^{\circledR}$ (Bayer AG, Leverkusen, Germany) in 2005, in combination with praziquantel, and subsequently as Procox ${ }^{\circledR}$ (Bayer AG, Leverkusen, Germany), in combination with toltrazuril.

Because of its unique mechanism of action relative to other anthelmintics, emodepside is active at various stages in the nematode life-cycle. ${ }^{9,10}$ Pre-clinical pharmacology studies using in-vitro and in-vivo models of human filarial infections, including onchocerciasis, showed that emodepside is a potential candidate for human use. ${ }^{11,12}$ A concentration of $100 \mathrm{ng} / \mathrm{mL}\left(10^{-7} \mathrm{M}\right)$ of emodepside was found to be consistently active on parasites across several filarial species and stages, and a minimum inhibitory concentration of $10^{-7} \mathrm{M}$ was chosen as the target effective concentration in humans.

Here we report the pharmacokinetics (PK) and safety of emodepside after single and multiple doses in healthy male subjects, as well as the bioavailability of various tablet formulations.

\section{Methods}

\subsection{General}

The study designs are presented in Table 1. The initial doses were selected based on the predicted human PK and therapeutic dose, derived from data obtained from in vitro and in vivo studies after administration of emodepside to rats and dogs, and from in vitrodata on plasma-protein binding and blood-plasma partitioning. ${ }^{13}$

The three studies were approved by local research ethics committees in the United Kingdom and were conducted in compliance with the Declaration of Helsinki and the International Conference on Harmonisation E6 Guideline for Good Clinical Practice. A clinical trial authorisation was obtained from the Medicines and Healthcare products Regulatory Agency (U.K.) for each study. The studies were registered at clinicaltrials.gov and in EudraCT. Written informed consent was obtained from all subjects before undertaking any studyrelated procedures. Quality assurance, data management and study monitoring were performed by contract research organisations (Hammersmith Medicines Research, London U.K. and Niche Science and Technology, Richmond U.K.).

\subsection{Investigational Product (IP)}

Emodepside and placebo were supplied as a liquid service formulation (LSF) and in three different tablet formulations. The LSF was a $0.1 \%(\mathrm{w} / \mathrm{v})$ solution containing $1 \mathrm{mg}$ emodepside per $\mathrm{mL}$. Conventional immediate-release (IR) tablets containing emodepside in crystalline form were supplied in two dosage strengths, 5 and $20 \mathrm{mg}$, for the single ascending dose (SAD) study. The tablets used in the relative bioavailability (RBA) study were amorphous solid dispersion (ASD) tablets containing $5 \mathrm{mg}$ of emodepside in amorphous form, embedded in either a gastroresistant polymer or a gastrosoluble polymer.

The LSF, tablets and matching placebos were developed and manufactured by Bayer AG. Manufacturing, packaging, quality control and preparation of clinical supplies complied with Good Manufacturing Practice. 
Randomisation, using a pre-determined randomisation list and IP allocation, was performed by research personnel not involved in any other study-related activity.

\subsection{Subjects}

At screening, subjects were deemed healthy based on medical history, physical examination, ECG, vital signs and laboratory tests. Key non-inclusion criteria included presence or history of severe allergies, recent use of any prescription medicine, blood loss $>400 \mathrm{~mL}$ or participation in another clinical study in the past 3 months.

To preclude any dietary effects on the PK of emodepside, subjects in the fasting cohorts fasted for 9 hours (10 hours in the RBA study) before receiving the IP. Subjects in the fed cohorts fasted for 10 hours prior to dosing and received a standard high-calorie, high-fat breakfast 30 minutes prior to dosing.

\subsection{PK Analyses}

Emodepside concentrations were determined by a validated high performance liquid chromatography-tandem mass spectrometry assay. Deuterated emodepside- $\mathrm{D}_{16}$ was used as the internal standard. The lower limit of quantitation for emodepside in plasma was $1 \mathrm{ng} / \mathrm{mL}$. Values below this limit were not used to calculate the PK parameters, except values that were below the limit of quantification before $\mathrm{C}_{\max }$, which were set to zero.

The highest observed plasma concentration $\left(\mathrm{C}_{\max }\right)$ was determined directly from concentration-time data, as was the time to reach maximum plasma concentration $\left(t_{\max }\right)$. The area under the plasma concentrationtime curve from time zero (pre-dose) to the time of last quantifiable concentration $\left(\mathrm{AUC}_{0 \text {-last }}\right)$ was calculated using the linear-log trapezoidal rule. Elimination half-life $\left(t_{1 / 2}\right)$ was calculated by the equation $1 \mathrm{n} 2 / \lambda_{z}$.

\subsection{Safety Assessments}

Safety was assessed by monitoring adverse events (AEs) throughout the studies. Other safety monitoring included 12-lead ECG recordings, measurement of vital signs, physical and neurological examinations, haematology, biochemistry and urinalysis. To minimise risks in the SAD and multiple ascending dose (MAD) studies, subjects were dosed sequentially using sentinels in each cohort (1 IP, 1 placebo) as per EMA guidelines. ${ }^{14}$ If the previous dose was well tolerated, with no safety concerns, dose escalation was decided by the Safety Review Group after reviewing safety and PK data from all available cohorts. Moreover, treatment with the highest dose in the SAD study was repeated for regular ophthalmological evaluations to better characterise AEs observed in the SAD study. Regular ophthalmological assessments were also performed in the MAD study.

\subsection{Statistical Analyses}

Statistical analyses were performed using SAS ${ }^{\circledR}$ version 9.3 (Cary, NC, USA). Demographic data and baseline characteristics were listed and summarised. Safety data did not undergo formal statistical analysis. PK parameters were derived from plasma-concentration versus time data using a non-compartmental analysis in Phoenix WinNonlin version 7 (Certara Inc., Princeton, NJ, USA). Plasma-concentration versus time data and PK parameters were listed, and summarised by treatment, using descriptive statistics. Mean concentrations were calculated only if at least $2 / 3$ of the individual concentrations were above the lower limit of quantification (LLOQ). Individual subject and mean plasma concentrations were displayed graphically. Planned sampling times were used to summarise plasma-concentration data; actual sampling times were used in the derivation of PK parameters.

\section{Results}

\subsection{Subject Disposition}

Demographic characteristics were consistent across the three studies (Table 2). In the SAD study, one subject in the $1 \mathrm{mg}$ LSF cohort was withdrawn from the study due to an AE. He received an incomplete dose of $0.1 \mathrm{mg}$ emodepside in error. He was included in the safety assessment, but not the PK assessments. Only 
5 of the planned 6 subjects were included in the $5 \mathrm{mg}$ IR tablet cohort. In the MAD study, all subjects received the IP as intended. In the RBA study, only 55 of the planned 60 subjects were included in Part 1 , and only 22 of the planned 24 subjects in Part 2. In addition, in Part 1, two subjects withdrew from the study, however their data were included in the PK and safety assessments, up to 48 hours post-dose for one and up to 120 hours post-dose for the other.

\subsection{PK Parameters}

\subsubsection{Single Ascending Dose Study}

Mean plasma emodepside concentration-time profiles are shown in Figure 1, and PK parameters are presented in Table 3. Across all doses and for both formulations, after single administration, emodepside concentrations were rapidly quantifiable in the plasma, starting with the first timepoint at 0.5 hours post-dose. Median $\mathrm{t}_{\max }$ in subjects in the fasting state was shorter for the LSF than for the IR tablet. Exposure, based on $\mathrm{C}_{\max }$ and $\mathrm{AUC}_{0-24}$, was dose-proportional with the LSF up to the $40 \mathrm{mg}$ dose, but less than dose proportional with the IR tablet. The relative bioavailability of the conventional tablet versus the LSF was $35.0 \%$ for the $5 \mathrm{mg}$ dose and $11.7 \%$ for the $20 \mathrm{mg}$ dose (Table 4 ).

In the fed state, after a single $10 \mathrm{mg}$ dose of the $\mathrm{LSF}$, geometric mean $\mathrm{C}_{\max }$ and $\mathrm{AUC}_{0-24}$ were lower and median $t_{\max }$ was longer than after the same dose in the fasting state, indicating delayed absorption of emodepside; bioavailability over the first 24 hours post-dose was lower in the fed state as compared to fasting (Table 3).

Geometric mean $t_{1 / 2}$ at all dose levels and for both formulations was very long, while geometric mean $\mathrm{t}_{1 / 2}$ during the first 24 hours post-dose was much shorter. Indeed, plasma emodepside concentrations were approximately $90 \%$ lower, based on geometric mean $\mathrm{C}_{\max }$, in the first 24 hours post-dose.

\subsubsection{Multiple Ascending Dose Study}

Mean plasma emodepside concentration-time profiles are shown in Figure 2 and PK parameters are presented in Table 5. Rapid absorption of emodepside and the median $t_{\max }$ seen in the SAD study were confirmed across all dosing groups and regimens in the MAD study. Emodepside levels were still quantifiable in all subjects at the final sampling timepoint, 507 hours after the last morning dose, which was consistent with the findings in the SAD study.

$\mathrm{C}_{\max }$ and $\mathrm{AUC}$ increased in a dose-proportional manner after once daily (OD) dosing of 5 and $10 \mathrm{mg}$ emodepside LSF. Exposure was higher after dosing with $10 \mathrm{mg}$ twice daily (BID) than with $10 \mathrm{mg}$ OD. Compared to pre-dose concentrations on Days 1-8, $\mathrm{C}_{\text {trough }}$ levels in the $5 \mathrm{mg}$ OD, $10 \mathrm{mg}$ OD and $10 \mathrm{mg}$ BID groups before the last dose on Day 9 indicated that steady state had still not been reached.

Elimination $t_{1 / 2}$ was independent of dose with a geometric mean terminal $t_{1 / 2}$ on Day 9 of 419 hours in the $5 \mathrm{mg}$ OD group, 450 hours in the $10 \mathrm{mg}$ OD group and 508 hours in the $10 \mathrm{mg}$ BID group (Table 5). Plasma concentrations declined from $\mathrm{C}_{\max }$ more rapidly during the 24 hours post-dose than subsequently, again consistent with the findings in the SAD study.

The increase in plasma emodepside concentrations after the last dose on Day 9 was lower after $10 \mathrm{mg}$ BID than after $10 \mathrm{mg} \mathrm{OD}$, with $\mathrm{C}_{\max } / \mathrm{C}_{\text {trough }}$ ratios of 1.9 and 3.0, respectively. Although the total daily dose in the $10 \mathrm{mg}$ BID group was double that in the $10 \mathrm{mg}$ OD group on Days $0-8$, geometric mean $\mathrm{C}_{\max }$ on Day 9 was only 1.2 -fold higher in the $10 \mathrm{mg}$ BID group than in the $10 \mathrm{mg}$ OD group.

\subsubsection{Relative Bioavailability Study}

Mean plasma emodepside concentration-time profiles are shown in Figure 3 and PK parameters are presented in Table 6. The bioavailability of the two ASD tablets relative to the reference formulation, emodepside $5 \mathrm{mg}$ LSF, was lower, with least square mean ratios (test/reference) ranging from $66 \%$ to $80 \%$ for $\mathrm{AUC}_{0-7 \mathrm{~d} / \mathrm{D} \text { and }}$ $40 \%$ to $77 \%$ for $\mathrm{C}_{\max / \mathrm{D}}$ (Table 7 ). The gastrosoluble tablet was more bioavailable than the gastroresistant tablet. Bioavailability was lower in the fed state, and the rate of absorption was slower with the tablets. The 
extent of the food effect was similar for the two tablets. The geometric mean $t_{1 / 2}$ up to 168 hours post-dose was 20 to 25 -fold longer than the geometric mean $t_{1 / 2}$ up to 24 hours post-dose.

\subsection{Safety}

Safety monitoring across all three studies did not identify any major concerns. Only one SAE occurred in the MAD study, an abscess requiring hospitalisation for surgery, but was not considered treatment-related. Mild to moderate non-serious treatment-related treatment-emergent adverse events (TEAEs) were reported in all three studies.

In the SAD, the onset of TEAEs involving visual disorders occurred at approximately $t_{\text {max }}$, but with no clear evidence that they were directly related to plasma emodepside concentrations, since the duration ranged from 1 hour to 1 day. Drug-related visual disorder TEAEs were reported after doses of 10, 20 and $40 \mathrm{mg}$ LSF in the fasting state (Table 8) but were all mild and resolved spontaneously within 24 hours. Onset ranged from 20 minutes to 4 hours post-dose, most often 1 to 2.5 hours post-dose. The occurrence of drug-related visual disorder TEAEs increased with emodepside dose.

Cases involving transient, mild visual disturbances, considered drug-related, also occurred in the MAD study, frequently associated with mild euphoria (Table 9). One subject treated with the lower dose also reported blurred vision of moderate intensity. Unlike in the SAD study, there was no clear relationship between the frequency of visual AEs and the dose of emodepside up to $10 \mathrm{mg}$ BID, however, the duration of visual AEs was longer after $10 \mathrm{mg}$ emodepside BID, with intermittent symptoms recurring up to 21 days. Based on these observations, $10 \mathrm{mg}$ emodepside BID was considered to be the maximum tolerated dose as the LSF in the MAD study.

Across both parts of the RBA study and consistent with findings from the SAD study, the most frequent drug-related TEAEs involved visual disorders (2 subjects) (Table 10), with onset around $t_{\max }, 1.5-2$ hours after dosing with the gastrosoluble ASD tablet at 5 or $10 \mathrm{mg}$ in the fasting state. In both cases, another drug-related TEAE, i.e. dizziness and feeling of relaxation, respectively, coincided with visual disturbances. Notably, subjects who received the gastrosoluble tablet at $10 \mathrm{mg}$ in the fasting state (in which 1 subject reported 2 concomitant treatment-related TEAEs: visual disturbances and feeling of relaxation) had the highest geometric mean $\mathrm{C}_{\max }$ and $\mathrm{AUC}_{0-7 \mathrm{~d}}$. However, no drug-related TEAEs were reported in either the $5 \mathrm{mg}$ LSF or $10 \mathrm{mg}$ gastroresistant ASD tablet groups in the fasting state, both of which had higher mean $\mathrm{C}_{\max }$ and $\mathrm{AUC}_{0-7 \mathrm{~d}}$ than the $5 \mathrm{mg}$ gastrosoluble ASD tablet fasting group in which three treatment-related TEAEs occurred: visual disturbances and dizziness, concomitantly in one subject. Thus, the results in the RBA study indicated that the gastrosoluble ASD tablet provided overall exposure closer to that of the LSF, but with a better safety profile.

\section{Discussion}

De novo discovery and development of new therapeutics is an extremely costly and time-consuming process that is rarely conducted for neglected tropical diseases, including onchocerciasis, where drug discovery is notoriously under-funded. Since emodepside is a registered product in animal health, the present studies confirm the usefulness of drug repurposing as a strategy for identifying and developing new therapeutic agents. Its safety and efficacy profiles are well established after nearly 15 years of use in the veterinary setting. As expected, the early development results in healthy male subjects from the three Phase I studies reported here show promising safety profiles.

Across all three Phase I clinical studies, emodepside was found to be rapidly absorbed under fasting conditions. Dose-proportional increases in plasma emodepside concentrations were observed with increasing doses from $1 \mathrm{mg}$ to $40 \mathrm{mg}$ after oral administration of the LSF. Conventional IR tablets containing $5 \mathrm{mg}$ or $20 \mathrm{mg}$ crystalline emodepside were somewhat more slowly and poorly absorbed as compared to the LSF.

The half-life during the first 24 hours after dosing, i.e. during the distribution-elimination phase, was short at around 11 hours, and was followed by a very long terminal elimination half-life, estimated at $>500$ hours. Owing to the long terminal elimination half-life, steady state was not reached after repeated dosing 
with emodepside for 10 days in the MAD study. In all three studies, plasma concentration-time profiles for emodepside showed a distinct biphasic pattern in the descending part of the curve, which is postulated to reflect initial rapid distribution of the compound followed by very slow terminal elimination. This finding is particularly promising since rapid distribution of emodepside in the tissues suggests that exposure of the parasites may be high, given that microfilariae reside mainly in the skin and adult worms in subcutaneous tissue. This hypothesis is backed up by preclinical findings with radio-labelled emodepside, showing that radioactivity levels were higher in most tissues than in the blood, the highest concentrations being detected in the fat at all time-points. In addition, the long terminal half-life is expected to be advantageous in maintaining patient exposure to pharmacodynamically active drug levels. The long half-life is not expected to raise any safety issues, based on the available toxicological data and the safety profile of emodepside across the three studies.

In both studies comparing dosage forms, the LSF showed consistently higher bioavailability than the tablet formulations. Indeed, in the SAD study, the conventional IR tablet containing crystalline emodepside had insufficient bioavailability compared to the LSF and was considered unsuitable for further study. This is due to the biopharmaceutical properties of emodepside, and optimisation of the dosage form was required to improve the dissolution kinetics. New ASD tablets containing $5 \mathrm{mg}$ emodepside in amorphous form were developed and showed markedly better bioavailability. The gastrosoluble ASD tablet was more bioavailable than the gastroresistant ASD tablet. With both ASD tablets, intake under fed conditions slowed the rate of absorption of emodepside and reduced its bioavailability. Based on data from the RBA study, a $15 \mathrm{mg}$ dose with the gastrosoluble ASD tablet is predicted to provide equivalent exposure to $10 \mathrm{mg}$ LSF.

From the outset it was known that, for logistical reasons, the liquid formulation would not be practical for use in the field in Phase II and III studies in countries where onchocerciasis is endemic. Nevertheless, as these Phase I studies showed, the LSF leads to higher exposure as compared to the tablet formulations, making it useful in assessing the safety profile. Overall, TEAEs were more frequent with the LSF, particularly at higher doses.

No important safety risks, either potential or identified, have been identified with emodepside to date. Safety data accrued in the three Phase I studies indicate that potential effects on the central nervous system and vision will require close monitoring in future studies.

Lastly, in the MAD study, the increase in plasma emodepside concentration after the final dose of the LSF on Day 9 was lower after $10 \mathrm{mg}$ BID than after $10 \mathrm{mg}$ OD, with $\mathrm{C}_{\max } / \mathrm{C}_{\text {trough }}$ ratios of 1.9 and 3.0, respectively (data on file). Although the total daily dose in the $10 \mathrm{mg}$ BID dosing group was twice as high as that in the $10 \mathrm{mg}$ OD dosing group on Days 0-8, geometric mean $\mathrm{C}_{\max }$ on Day 9 was only 1.2 -fold higher in the 10 mg BID dosing group compared to the $10 \mathrm{mg}$ OD group. This suggested that twice-daily dosing might be beneficial in mitigating any adverse effects related to $\mathrm{C}_{\max }$, thereby improving tolerability.

Thus, the three Phase I studies provided invaluable information on the safety, PK profile and relative bioavailability of emodepside in healthy humans. The LSF is not suitable for easy and accurate clinical use under the conditions expected for patients treated for onchocerciasis, and the Phase I data enabled us to select a field-adapted tablet formulation compatible with the biopharmaceutical properties of emodepside. We also identified a dose and dosing regimen that will achieve the target effective concentration in humans, i.e. $100 \mathrm{ng} / \mathrm{mL}\left(10^{-7} \mathrm{M}\right)$ of emodepside, and open the way for Phase II and III studies in individuals infected with $O$. volvulus .

\section{e) Acknowledgments}

The authors wish to thank Graham Smith for editorial assistance.

\section{f) Conflict of Interest Statement}

The authors declare that they have no conflicts of interest.

\section{g) Funding Information}


The studies were funded in part by grants from the Bill \& Melinda Gates Foundation, USA (Grant no. OPP1111431); the US Agency For International Development (USAID), USA (Grant no. AID-OAA-G1400010); and the Federal Ministry of Education and Research (BMBF) through KfW, Germany (Grant 615-73099-MT2016KFW). For its overall mission, DND $i$ also receives financial support from UK aid, UK; Medecins Sans Frontieres (MSF) International; and the Swiss Agency for Development and Cooperation (SDC), Switzerland.

\section{h) Data Availability Statement}

The data that support the findings of this study are available on request from the corresponding author. The data are not publicly available due to privacy or ethical restrictions.

\section{i) References}

1. World Health Organisation. Onchocerciasis (river blindness) - Disease Information https://www.who.int/blindness/partnerships/onchocerciasis_disease_information/en/_consulted on 14 April 2020.

2. Kuesel AC. Research for new drugs for elimination of onchocerciasis in Africa. Int J Parasitol Drugs Drug Resist. 2016 May 19. pii: S2211-3207(16)30015-X. doi:10.1016/j.ijpddr.2016.04.002

3. Taylor MJ, Hoerauf A, Bockarie M. Lymphatic filariasis and onchocerciasis. Lancet. 2010 Oct 2;376(9747):1175-85. doi:10.1016/S0140-6736(10)60586-7. Epub 2010 Aug 23.

4. Bah GS, Tanya VN, Makepeace BL. Immunotherapy with mutated onchocystatin fails to enhance the efficacy of a sub-lethal oxytetracycline regimen against Onchocerca ochengi. Vet Parasitol. 2015 Aug 15;212(1-2):25-34. doi:10.1016/j.vetpar.2015.06.005. Epub 2015 Jun 12.

5. Opoku NO, Bakajika DK, Kanza EM, et al. Single dose moxidectin versus ivermectin for Onchocerca volvulus infection in Ghana, Liberia, and the Democratic Republic of the Congo: a randomised, controlled, double-blind phase 3 trial. Lancet. 2018;392(10154):1207-1216.

6. Pleiss U, Harder A, Turberg A, Londershausen M, Iinuma K, Mencke N, Jeschke P, Bonse G. Synthesis of a radiolabeled cyclodepsipeptide [3H-methyl] PF1022A. J Labelled Comp Radiopharm. 1996;38:619.

7. Omura S, Crump A. The life and times of ivermectin — a success story. Nat Rev Microbiol 2004;2:984989.

8. Cotreau MM, et al. The antiparasitic moxidectin: Safety, tolerability, and pharmacokinetics in humans. J Clin Pharmacol 2003;43:1108-1115

9. von Samson-Himmelstjerna G, Harder A, Sangster NC, Coles GC. Efficacy of two cyclooctadepsipeptides, PF1022A and emodepside, against anthelmintic-resistant nematodes in sheep and cattle. Parasitol. 2005;130:343-7.

10. Geary TG, Woo K, McCarthy JS, Mackenzie CD, Horton J, Prichard RK, de Silva NR, Olliaro PL, Lazdins-Helds JK, Engels DA, Bundy DA. Unresolved issues in anthelmintic pharmacology for helminthiases of humans. Int J Parasitol. 2010 Jan;40(1):1-13. doi: 10.1016/j.ijpara.2009.11.001.

11. Zahner $\mathrm{H}$ et al. Filaricidal efficacy of anthelmintically active cyclodepsipeptides. International Journal for Parasitology. 2001;31:1515-1522.

12. Zahner $\mathrm{H}$ et al. Effects of Bay 44-4400, a new cyclodepsipeptide, on developing stages of filariae (Acanthocheilonema viteae, Brugia malayi, Litomosoides sigmodontis ) in the rodent Mastomys coucha. Acta Tropica 2001 Sep 1;80(1).

13. Drugs for Neglected Diseasesinitiative . Investigator Brochure Emopdepside - BAY 44-4400. Version 3 dated 8 September 2017.

14. Committee for Medicinal Products for Human Use (CHMP). Guideline on strategies to identify and mitigate risks for first-in-human and early clinical trials with investigational medicinal products. EMEA/CHMP/SWP/28367/07 Rev. 1. 20 July 2017.

Data available on request from the authors.

\section{j) Tables}


Table 1. Overview of the Three Phase I studies on Emodepside

\begin{tabular}{|c|c|c|c|}
\hline & $\begin{array}{l}\text { SAD Study } \\
\text { First-in-human study }\end{array}$ & MAD Study & RBA Study \\
\hline Design features & $\begin{array}{l}\text { Two-part, } \\
\text { single-centre, } \\
\text { double-blind, } \\
\text { randomised, } \\
\text { placebo-controlled, } \\
\text { parallel-group, } \\
\text { single-ascending-dose, } \\
\text { comparative study }\end{array}$ & $\begin{array}{l}\text { Single-centre, } \\
\text { double-blind, } \\
\text { randomised, } \\
\text { placebo-controlled, } \\
\text { parallel-group, } \\
\text { multiple-ascending- } \\
\text { dose } \\
\text { study }\end{array}$ & $\begin{array}{l}\text { Two-part, randomised, } \\
\text { open-label, single-dose, } \\
\text { comparative } \\
\text { parallel-group study }\end{array}$ \\
\hline Study groups & $\begin{array}{l}10 \text { cohorts of } 8 \text { subjects } \\
\text { each; } 6 \text { on emodepside, } 2 \\
\text { on placebo }\end{array}$ & $\begin{array}{l}3 \text { cohorts of } 8 \text { subjects } \\
\text { each; } 6 \text { on emodepside, } 2 \\
\text { on placebo }\end{array}$ & $\begin{array}{l}7 \text { cohorts of } 12 \text { subjects } \\
\text { each; all on emodepside }\end{array}$ \\
\hline Study population & Healthy male subjects & Healthy male subjects & Healthy male subjects \\
\hline Objectives & $\begin{array}{l}\text { Cohorts } 1 \text { to 8: assess } \\
\text { safety, tolerability and } \\
\text { PK of single ascending } \\
\text { oral doses. Cohort 9: } \\
\text { assess food effect on } \\
\text { bio-availability of LSF } \\
\text { Cohort 10: explore } \\
\text { relationship between } \\
\text { emodepside and AEs } \\
\text { reported in Part 1, in } \\
\text { particular } \\
\text { ophthalmological events }\end{array}$ & $\begin{array}{l}\text { Assess safety, tolerability, } \\
\text { PK and PD of multiple } \\
\text { ascending oral doses of } \\
\text { LSF over } 10 \text { days }\end{array}$ & $\begin{array}{l}\text { Assess PK (including } \\
\text { food effect), safety and } \\
\text { tolerability of two new } \\
\text { ASD tablet formulations, } \\
\text { a GR tablet and a GS } \\
\text { tablet, compared to the } \\
\text { LSF }\end{array}$ \\
\hline Doses studied & $\begin{array}{l}\text { Cohorts } 1 \text { to } 8: \text { LSF at } 1 \\
\text { mg, } 2.5 \mathrm{mg}, 5 \mathrm{mg}, 10 \mathrm{mg} \\
\text { or } 20 \mathrm{mg} \text { under fasting } \\
\text { conditions; IR tablet: } 5 \\
\text { mg or } 20 \mathrm{mg} \text { under } \\
\text { fasting conditions; } \\
\text { Cohort 9: LSF at } 10 \mathrm{mg} \\
\text { under fed conditions } \\
\text { Cohort 10: } 40 \mathrm{mg} \text { under } \\
\text { fasting conditions }\end{array}$ & $\begin{array}{l}\text { Cohort } 1: 5 \mathrm{mg} \text { once } \\
\text { daily for } 10 \text { days; Cohort } \\
\text { 2: } 10 \mathrm{mg} \text { once daily for } \\
10 \text { days; Cohort } 3: 10 \mathrm{mg} \\
\text { twice daily for } 10 \text { days } \\
\text { (single intake on last } \\
\text { day). }\end{array}$ & $\begin{array}{l}\text { Once daily dosing: } \\
\text { Cohort A: } 5 \mathrm{mg} \text { LSF, } \\
\text { fasting; Cohort B: } 5 \mathrm{mg} \\
\text { GR tablet, fasting; } \\
\text { Cohort C: } 5 \mathrm{mg} \text { GS } \\
\text { tablet, fasting; Cohort D: } \\
5 \text { mg GR tablet, fed; } \\
\text { Cohort E: } 5 \mathrm{mg} \text { GS } \\
\text { tablet, fed; Cohort F: } 10 \\
\text { mg GR tablet, fasting } \\
\text { Cohort G: } 10 \mathrm{mg} \text { GS } \\
\text { tablet, fasting }\end{array}$ \\
\hline $\begin{array}{l}\text { PK sample } \\
\text { collection }\end{array}$ & $\begin{array}{l}\text { Pre-dose, at frequent } \\
\text { timepoints up to } 24 \\
\text { hours post-dose, at } \\
\text { regular timepoints up } \\
\text { to } 168 \text { hours post-dose } \\
\text { and at } 3 \text { weeks } \\
\text { post-dose }\end{array}$ & $\begin{array}{l}\text { Pre-dose, at frequent } \\
\text { timepoints up to } 15 \\
\text { hours post-dose at } \\
\text { regular timepoints up } \\
\text { to Day } 30 \text { post-dose }\end{array}$ & $\begin{array}{l}\text { Pre-dose, at frequent } \\
\text { timepoints up to } 24 \\
\text { hours post-dose and at } \\
\text { regular timepoints up } \\
\text { to } 168 \text { hours post-dose }\end{array}$ \\
\hline
\end{tabular}

AE: adverse event; ASD: amorphous solid dispersion; BID: twice daily; GR: gastroresistant; GS; gastrosoluble; IR: immediate release; LSF: liquid service formulation; MAD: multiple ascending dose; OD; once daily; 
PD: pharmacodynamics; PK: pharmacokinetics; RBA: relative bioavailability; SAD: single ascending dose

Table 2. Demographic Characteristics of Subjects in the Three Phase I Studies on Emodepside

\begin{tabular}{lllllll}
\hline Variable & Statistics & SAD Study & SAD Study & MAD Study & RBA Study & RF \\
\hline \multirow{3}{*}{ Sex } & & Part 1 N=63 & Part 2 N = 16 & N=24 & Part 1 N=55 & Pa \\
Age (years) & Male n (\%) & $63(100)$ & $16(100)$ & $24(100)$ & $55(100)$ & 22 \\
& Mean (SD) & $32.4(8.89)$ & $34.4(11.05)$ & $31.3(8.03)$ & $31.5(6.78)$ & 30. \\
Ethnicity & Median (range) & $32(19-54)$ & $34.0(21-52)$ & $31.0(19-43)$ & $32.0(18-44)$ & 32. \\
& White n (\%) & $60(95.2)$ & $15(93.8)$ & $24(100)$ & $55(100)$ & 22 \\
Weight (kg) & Hispanic or Latino n (\%) & $3(4.8)$ & $1(6.3)$ & 0 & 0 & 0 \\
& Mean (SD) & $78.4(9.9)$ & $81.4(11.6)$ & $74.9(10.8)$ & $78.8(10.5)$ & 77. \\
BMI & Median (range) & $76.6(57.2-97.6)$ & $81.5(60-101.2)$ & $74.05(54.2-95.2)$ & $80.4(55.0-104.7)$ & 79. \\
& Mean (SD) & $24.4(2.4)$ & $25.2(3.1)$ & $22.9(2.7)$ & $24.3(2.77)$ & 24. \\
Tobacco use & Median (range) & $24.1(19.0-29.7)$ & $24.9(20.5-29.9)$ & $22.55(18.1-27.8)$ & $24.8(18.9-30.1)$ & 24. \\
Alcohol use & n (\%) & $6(9.5)$ & $1(6.3)$ & $4(16.7)$ & $13(23.7)$ & 7 \\
\hline
\end{tabular}

BMI: body-mass index; MAD: multiple ascending dose; n: number of subjects; RBA: relative bioavailability;

SAD: single ascending dose; SD: standard deviation

Table 3. Mean PK Parameters for Emodepside in the Single Ascending Dose Study

\begin{tabular}{|c|c|c|c|c|c|c|c|c|c|}
\hline & $\begin{array}{l}1 \mathrm{mg} \\
\mathrm{LSF} \\
\text { fasting }\end{array}$ & $\begin{array}{l}2.5 \mathrm{mg} \\
\text { LSF } \\
\text { fasting }\end{array}$ & $\begin{array}{l}5 \mathrm{mg} \\
\mathrm{LSF} \\
\text { fasting }\end{array}$ & $\begin{array}{l}10 \mathrm{mg} \\
\text { LSF } \\
\text { fasting }\end{array}$ & $\begin{array}{l}20 \mathrm{mg} \\
\text { LSF } \\
\text { fasting }\end{array}$ & $\begin{array}{l}40 \mathrm{mg} \\
\text { LSF } \\
\text { fasting }\end{array}$ & $\begin{array}{l}5 \mathrm{mg} \\
\text { IRT } \\
\text { fasting }\end{array}$ & $\begin{array}{l}20 \mathrm{mg} \\
\text { IRT } \\
\text { fasting }\end{array}$ & \\
\hline AUC $\mathbf{C l a s t}_{\text {lat }}$ & 182 & 845 & 1700 & 3070 & 7480 & 16400 & 501 & 667 & 3 \\
\hline (hng/mL) & 111 & 10.4 & 24.2 & 27.7 & 22.1 & 23.6 & 76.8 & 125 & 20 \\
\hline $\mathrm{AUC}_{0-24}$ & 100 & 2506.5 & 522 & 996 & 1910 & 4110 & 183 & 223 & 67 \\
\hline (hng/mL) & 50.4 & & 25.8 & 21.2 & 16.3 & 33.6 & 24.3 & 58.0 & 26 \\
\hline $\mathrm{AUC}_{0-24} / \mathrm{D}$ & 100 & 100 & 104 & 99.6 & 95.3 & 103 & 36.5 & 11.2 & 67 \\
\hline$([\mathrm{hng} / \mathrm{mL}] / \mathrm{m}$ & $1 \bar{g}) .4$ & 6.50 & 25.8 & 21.2 & 16.3 & 33.6 & 24.3 & 58.0 & 26 \\
\hline $\mathbf{C}_{\max }$ & 18.6 & 37.6 & 92.1 & 172 & 306 & 595 & 25.7 & 30.2 & 71 \\
\hline$(\mathrm{ng} / \mathrm{mL})$ & 20.8 & 15.5 & 16.2 & 32.3 & 28.7 & 27.9 & 23.9 & 62.5 & \\
\hline $\mathrm{C}_{\max } / \mathrm{D}$ & 18.6 & 15.0 & 18.4 & 17.2 & 15.3 & 14.9 & 5.15 & 1.51 & \\
\hline$([\mathrm{ng} / \mathrm{mL}] / \mathrm{mg}$ & 20.8 & 15.5 & 16.2 & 32.3 & 28.7 & 27.9 & 23.9 & 62.5 & \\
\hline $\begin{array}{l}\mathbf{t}_{\max } \\
(\mathrm{h})\end{array}$ & $\begin{array}{l}1.00 \\
(1.00- \\
1.05)\end{array}$ & $\begin{array}{l}1.00 \\
(1.00- \\
2.50)\end{array}$ & $\begin{array}{l}1.00 \\
(1.00- \\
1.50)\end{array}$ & $\begin{array}{l}1.00 \\
(1.00- \\
1.00)\end{array}$ & $\begin{array}{l}1.50 \\
(1.00- \\
2.53)\end{array}$ & $\begin{array}{l}1.05 \\
(1.00- \\
8.00)\end{array}$ & $\begin{array}{l}2.00 \\
(1.02- \\
2.55)\end{array}$ & $\begin{array}{l}2.00 \\
(1.50- \\
2.02)\end{array}$ & \\
\hline Terminal & 42.7 & 449 & 415 & 365 & 590 & 392 & 267 & 348 & \\
\hline$t_{\frac{1}{2}}(h)$ & 531 & 74.0 & 117 & 286 & 68.1 & 31.7 & 392 & 171 & \\
\hline t & 8.45 & 10.6 & 11.6 & 10.9 & 10.5 & 11. 1 & 10.8 & 11.3 & \\
\hline $\begin{array}{l}\frac{1}{\frac{1}{2}} \mathbf{0 - 2 4} * \\
\text { (h) }\end{array}$ & 84.7 & 24.9 & 21.7 & 26.8 & 28.7 & 24.7 & 9.2 & 23.8 & \\
\hline
\end{tabular}

* Dominant half-life, defined as "half-life calculated from the terminal slope of the log concentration-time (0-24 hr) curve".

Note: all values are mean / CV\%, except $t_{\max }$, which is median (range).

IRT: immediate release tablet; LSF: liquid service formulation 
Table 4. Relative Bioavailability of Emodepside IR Tablet Compared to LSF in the SAD Study

\begin{tabular}{lllll}
\hline Dose & Geometric mean $\mathbf{A U C}_{\mathbf{0 - 2 4}}$ & Geometric mean $\mathbf{A U C}_{\mathbf{0 - 2 4}}$ & IR tablet versus LSF & IR tablet ver \\
\hline & IR tablet & $\mathbf{L S F}$ & $\mathbf{F}_{\text {rel }}(\boldsymbol{\%})$ & $\mathbf{9 0 \%} \mathbf{C I}$ \\
$5 \mathrm{mg}$, fasting & 182.5 & 521.9 & 34.97 & $26.56-46.03$ \\
$20 \mathrm{mg}$, fasting & 223.2 & 1905.8 & 11.71 & $7.73-17.75$ \\
\hline
\end{tabular}

$\mathrm{AUC}_{0-24}$ : dose normalised area under the concentration-time curve from 0 to 24 hours; CI: confidence interval; $\mathrm{F}_{\text {rel }}$ : relative bioavailability; IR: immediate release; LSF: liquid service formulation

Table 5. Mean PK parameters for emodepside in the multiple ascending dose study

\begin{tabular}{|c|c|c|c|c|}
\hline & $5 \mathrm{mg}$ OD LSF fasting & $5 \mathrm{mg}$ OD LSF fasting & $10 \mathrm{mg}$ OD LSF fasting & $10 \mathrm{mg}$ \\
\hline & Day 0 & Day 9 & Day 0 & Day 9 \\
\hline $\mathbf{A U C}_{\text {last }}(\mathrm{hng} / \mathrm{mL})$ & $-(-)$ & $19359(29.9)$ & $-(-)$ & 40655 \\
\hline $\mathbf{A} \mathbf{U C}_{\text {last }} / \mathbf{D}([\mathrm{hng} / \mathrm{mL}] / \mathrm{mg})$ & $-(-)$ & $3872(29.9)$ & $-(-)$ & $4065(4$ \\
\hline $\mathbf{A U C}_{\mathbf{0 - 2 4}}(\mathrm{hng} / \mathrm{mL})$ & $574(19.7)$ & $1689(31.3)$ & $1135(32.7)$ & $3487(4$ \\
\hline $\mathbf{A U C}_{\mathbf{0 - 2 4}} / \mathbf{D}([\mathrm{hng} / \mathrm{mL}] / \mathrm{mg})$ & $115(19.7)$ & $338(31.3)$ & $113(32.7)$ & $349(44$ \\
\hline $\mathbf{C}_{\max }(\mathrm{ng} / \mathrm{mL})$ & $93.8(17.8)$ & $149(17.9)$ & $186(21.3)$ & $287(39$ \\
\hline $\mathbf{C}_{\max } / \mathbf{D}([\mathrm{ng} / \mathrm{mL}] / \mathrm{mg})$ & $18.8(17.8)$ & $29.9(17.9)$ & $18.6(21.3)$ & $28.7(39$ \\
\hline $\mathbf{C}_{\text {trough* }}(\mathrm{ng} / \mathrm{mL})$ & $-(-)$ & $49.7(36.8)$ & $-(-)$ & $97.1(50$ \\
\hline $\mathbf{t}_{\max }(\mathrm{h})$ & $1.00(1.00-1.07)$ & $1.00(1.00-1.50)$ & $1.25(1.00-2.00)$ & $1.25(1$. \\
\hline Terminal $t_{\frac{1}{2}}(h)$ & $-(-)$ & $419(42.6)$ & $-(-)$ & $450(30$ \\
\hline $\mathrm{t}_{\frac{1}{2} 0-24} * *(\mathrm{~h})$ & $-(-)$ & $26.9(52.4)$ & $-(-)$ & $18.4(30$ \\
\hline$\lambda_{\zeta}(1 / \mathrm{h})$ & $-(-)$ & $0.00166(42.6)$ & $-(-)$ & 0.00154 \\
\hline $\mathbf{C L}_{\mathrm{ss}} / \mathbf{F}(\mathrm{L} / \mathrm{h})$ & $-(-)$ & $2.96(31.3)$ & $-(-)$ & $2.87(44$ \\
\hline $\mathbf{V}_{\mathbf{z}} / \mathbf{F}(\mathrm{L})$ & $-(-)$ & $1788(74.2)$ & $-(-)$ & $1861(6$ \\
\hline $\mathbf{M R T}_{\text {last }}(\mathrm{h})$ & $7.28(10.7)$ & $-(-)$ & $7.00(11.0)$ & $-(-)$ \\
\hline
\end{tabular}

* Before the final intake on Day 9

** Dominant half-life, defined as "half-life calculated from the terminal slope of the log concentration-time (0-24 hr) curve".

Note: all values are mean / CV\%, except $t_{\max }$, which is median (range).

LSF: liquid service formulation; OD: once daily; BID: bis in diem (twice daily)

Table 6. Mean PK parameters for emodepside in the relative bioavailability study

\begin{tabular}{|c|c|c|c|c|c|}
\hline & Part 1 & Part 1 & Part 1 & Part 1 & Par \\
\hline & LSF 5 mg & ASD tablet $5 \mathrm{mg}$ & ASD tablet $5 \mathrm{mg}$ & ASD tablet $5 \mathrm{mg}$ & ASI \\
\hline & Fasting $\mathrm{N}=11$ & GR fasting $N=11$ & GS fasting $N=10$ & GR fed $N=12$ & GS \\
\hline $\mathbf{A U C}_{\text {last }}(\mathrm{hng} / \mathrm{mL})$ & $1160(43.7)$ & $856(19.2)$ & $921(24.0)$ & $677(32.3)$ & 735 \\
\hline $\mathbf{A U C}_{\mathbf{0 - 7 d}}(\mathrm{hng} / \mathrm{mL})$ & $1215(37.2)$ & $852(19.1)$ & $931(23.3)$ & $67432.1)$ & 733 \\
\hline $\mathbf{A U C}_{\mathbf{0 - 7 d}} / \mathbf{D}([\mathrm{hng} / \mathrm{mL}] / \mathrm{mg})$ & $24337.2)$ & $170(19.1)$ & $186(23.3)$ & $135(32.1)$ & 147 \\
\hline $\mathbf{C}_{\max }(\mathrm{ng} / \mathrm{mL})$ & $88.5(20.1)$ & $41.9(20.0)$ & $54.2(35.3)$ & $27.1(26.8)$ & 36.2 \\
\hline $\mathbf{C}_{\max } / \mathbf{D}([\mathrm{ng} / \mathrm{mL}] / \mathrm{mg})$ & $17.7(20.1)$ & $8.38(20.0)$ & $10.8(35.3)$ & $5.41(26.8)$ & 7.24 \\
\hline$t_{\max }(\mathrm{h})$ & $1.00(0.50-1.50)$ & $4.00(2.50-6.00)$ & $1.50(1.00-2.52)$ & $5.01(1.50-8.00)$ & 3.00 \\
\hline Terminal $t_{\frac{1}{2}}(h)$ & $220(87.1)$ & $234(71.2)$ & $253(53.0)$ & $235(75.7)$ & 208 \\
\hline
\end{tabular}




\begin{tabular}{llllll}
\hline & Part 1 & Part 1 & Part 1 & Part 1 & Part \\
\hline $\mathbf{t}_{\frac{\mathbf{1}}{\mathbf{2}} \mathbf{0 - 2 4}} *(\mathrm{~h})$ & $11.0(31.6)$ & $10.0(20.6)$ & $11.0(29.1)$ & $10.5(22.9)$ & 11.1 \\
$\boldsymbol{\lambda}_{\zeta}(1 / \mathrm{h})$ & $0.00315(87.1)$ & $0.00296(71.2)$ & $0.00274(53.0)$ & $0.00295(75.7)$ & 0.003 \\
$\mathbf{M R T}_{\text {last }}(\mathrm{h})$ & $48.1(45.1)$ & $55.9(7.4)$ & $54.2(15.4)$ & $60.6(5.4)$ & 58.5 \\
\hline
\end{tabular}

* Dominant half-life, defined as "half-life calculated from the terminal slope of the log concentration-time (0-24 hr) curve".

Note: all values are mean / CV\%, except $t_{\max }$, which is median (range).

ASD: amorphous solid dispersion GR: gastroresistant; GS: gastrosoluble; LSF: liquid service formulation

Table 7. Relative bioavailability of gastroresistant and gastrosoluble emodepside ASD tablets (test) compared to $5 \mathrm{mg}$ LSF (reference) in the fasting state

\begin{tabular}{|c|c|c|c|c|c|c|}
\hline Parameter & IR tablets & IR tablets & $\begin{array}{l}\text { Least } \\
\text { square } \\
\text { means }\end{array}$ & $\begin{array}{l}\text { Least } \\
\text { square } \\
\text { means }\end{array}$ & $\begin{array}{l}\text { Test versus } \\
\text { reference }\end{array}$ & $\begin{array}{l}\text { Test versus } \\
\text { reference }\end{array}$ \\
\hline & Formulation & Dose (mg) & Test & $\begin{array}{l}\text { Reference } \\
\text { (LSF } 5 \text { mg) }\end{array}$ & Ratio (\%) & $90 \% \mathrm{CI}$ \\
\hline \multirow{4}{*}{$\begin{array}{l}\mathrm{AUC}_{0-7 \mathrm{~d}} / \mathrm{D} \\
([\mathrm{hng} / \mathrm{mL}] / \mathrm{mg})\end{array}$} & Gastroresistant & 5 & 170 & 243 & 70.1 & $56.7-86.6$ \\
\hline & & 10 & 161 & 243 & 66.2 & $51.4-85.4$ \\
\hline & Gastrosoluble & 5 & 186 & 243 & 76.6 & $60.8-96.5$ \\
\hline & & 10 & 194 & 243 & 80.0 & 63.0-102 \\
\hline \multirow{4}{*}{$\begin{array}{l}\mathrm{C}_{\max } / \mathrm{D} \\
([\mathrm{ng} / \mathrm{mL}] / \mathrm{mg})\end{array}$} & Gastroresistant & 5 & 8.40 & 17.7 & 47.4 & $40.9-54.8$ \\
\hline & & 10 & 7.20 & 17.7 & 40.5 & $34.0-48.3$ \\
\hline & Gastrosoluble & 5 & 10.8 & 17.7 & 61.3 & $49.8-75.6$ \\
\hline & & 10 & 13.5 & 17.7 & 76.6 & $62.1-94.4$ \\
\hline
\end{tabular}

ASD: amorphous solid dispersion; $\mathrm{AUC}_{0-7 \mathrm{~d}} / \mathrm{D}$ : dose normalised area under the concentration-time curve from 0 to 7 days; $\mathrm{C}_{\max } / \mathrm{d}$ : dose normalised peak plasma concentration; CI: confidence interval; ; LSF: liquid service formulation

Table 8. Treatment-emergent adverse events reported with emodepside and placebo in the single ascending dose study, presented by system organ class

\begin{tabular}{|c|c|c|c|c|c|c|c|c|c|c|c|c|c|}
\hline & $\begin{array}{l}\text { Part } \\
1\end{array}$ & $\begin{array}{l}\text { Part } \\
1\end{array}$ & $\begin{array}{l}\text { Part } \\
1\end{array}$ & $\begin{array}{l}\text { Part } \\
1\end{array}$ & $\begin{array}{l}\text { Part } \\
1\end{array}$ & $\begin{array}{l}\text { Part } \\
1\end{array}$ & $\begin{array}{l}\text { Part } \\
1\end{array}$ & $\begin{array}{l}\text { Part } \\
1\end{array}$ & $\begin{array}{l}\text { Part } \\
1\end{array}$ & $\begin{array}{l}\text { Part } \\
1\end{array}$ & $\begin{array}{l}\text { Part } \\
1\end{array}$ & $\begin{array}{l}\text { Part } \\
2\end{array}$ & $\begin{array}{l}\mathrm{Pa} \\
2\end{array}$ \\
\hline $\begin{array}{l}\text { System } \\
\text { Or- } \\
\text { gan } \\
\text { Class }\end{array}$ & $\begin{array}{l}\text { Placebo } \\
/ \\
\text { IRT } \\
\mathrm{N}=16 \\
\mathrm{n}(\%)\end{array}$ & $\begin{array}{l}\text { DSF } \\
\text { mg } \\
\text { LSF } \\
\mathrm{N}=1 \\
\mathbf{n} \\
(\%)^{\mathrm{a}}\end{array}$ & $\begin{array}{l}1 \mathrm{mg} \\
\mathrm{LSF} \\
\mathrm{N}=5 \\
\mathrm{n} \\
(\%)\end{array}$ & $\begin{array}{l}2.5 \\
\mathrm{mg} \\
\mathrm{LSF} \\
\mathrm{N}=6 \\
\mathrm{n} \\
(\%)\end{array}$ & $\begin{array}{l}5 \mathrm{mg} \\
\mathrm{LSF} \\
\mathrm{N}=6 \\
\mathrm{n} \\
(\%)\end{array}$ & $\begin{array}{l}5 \mathrm{mg} \\
\text { IRT } \\
\mathrm{N}=5 \\
\mathrm{n} \\
(\%)\end{array}$ & $\begin{array}{l}10 \\
\mathrm{mg} \\
\mathrm{LSF} \\
\mathrm{N}=6 \\
\mathrm{n} \\
(\%)\end{array}$ & $\begin{array}{l}20 \\
\mathrm{mg} \\
\mathrm{LSF} \\
\mathrm{N}=6 \\
\mathrm{n} \\
(\%)\end{array}$ & $\begin{array}{l}20 \\
\mathrm{mg} \\
\text { IRT } \\
\mathrm{N}=6 \\
\mathrm{n} \\
(\%)\end{array}$ & $\begin{array}{l}40 \\
\mathrm{mg} \\
\mathrm{LSF} \\
\mathrm{N}=6 \\
\mathrm{n} \\
(\%)\end{array}$ & $\begin{array}{l}\text { All } \\
\text { sub- } \\
\text { jects } \\
\mathrm{N}=63 \\
\mathrm{n} \\
(\%)\end{array}$ & $\begin{array}{l}\text { Placebo } \\
\text { LSF } \\
/ \\
\text { IRT } \\
\mathrm{N}=4 \\
\mathrm{n}(\%)\end{array}$ & $\begin{array}{c}10 \\
\mathrm{mg} \\
\text { LSI }\end{array}$ \\
\hline $\begin{array}{l}\text { Any } \\
\text { TEAE }\end{array}$ & $\begin{array}{l}6 \\
(37.5)\end{array}$ & $\begin{array}{l}1 \\
(100)\end{array}$ & $\begin{array}{l}3 \\
(60.0)\end{array}$ & 0 & $\begin{array}{l}3 \\
(50.0)\end{array}$ & $\begin{array}{l}3 \\
(60.0)\end{array}$ & $\begin{array}{l}5 \\
(83.3)\end{array}$ & $\begin{array}{l}3 \\
(50.0)\end{array}$ & $\begin{array}{l}2 \\
(33.3)\end{array}$ & $\begin{array}{l}5 \\
(83.3)\end{array}$ & $\begin{array}{l}31 \\
(49.2)\end{array}$ & 0 & $\begin{array}{l}3 \\
(5)\end{array}$ \\
\hline
\end{tabular}




\begin{tabular}{|c|c|c|c|c|c|c|c|c|c|c|c|c|c|}
\hline & $\begin{array}{l}\text { Part } \\
1\end{array}$ & $\begin{array}{l}\text { Part } \\
1 \\
\end{array}$ & $\begin{array}{l}\text { Part } \\
1\end{array}$ & $\begin{array}{l}\text { Part } \\
1 \\
\end{array}$ & $\begin{array}{l}\text { Part } \\
1\end{array}$ & $\begin{array}{l}\text { Part } \\
1 \\
\end{array}$ & $\begin{array}{l}\text { Part } \\
1 \\
\end{array}$ & $\begin{array}{l}\text { Part } \\
1 \\
\end{array}$ & $\begin{array}{l}\text { Part } \\
1 \\
\end{array}$ & $\begin{array}{l}\text { Part } \\
1 \\
\end{array}$ & $\begin{array}{l}\text { Part } \\
1\end{array}$ & $\begin{array}{l}\text { Part } \\
2\end{array}$ & $\begin{array}{l}\text { Par } \\
2\end{array}$ \\
\hline $\begin{array}{l}\text { Nervous } \\
\text { sys- } \\
\text { tem } \\
\text { disorders }\end{array}$ & $\begin{array}{l}2 \\
(12.5)\end{array}$ & 0 & $\begin{array}{l}2 \\
(40.0)\end{array}$ & 0 & $\begin{array}{l}1 \\
(16.7)\end{array}$ & $\begin{array}{l}1 \\
(20.0)\end{array}$ & $\begin{array}{l}1 \\
(16.7)\end{array}$ & $\begin{array}{l}1 \\
(16.7)\end{array}$ & $\begin{array}{l}1 \\
(16.7)\end{array}$ & $\begin{array}{l}3 \\
(50.0)\end{array}$ & $\begin{array}{l}12 \\
(19.0)\end{array}$ & 0 & $\begin{array}{l}2 \\
(33 .\end{array}$ \\
\hline $\begin{array}{l}\text { Eye } \\
\text { disorders }\end{array}$ & $\begin{array}{l}1 \\
(6.2)\end{array}$ & 0 & 0 & 0 & 0 & $\begin{array}{l}1 \\
(20.0)\end{array}$ & $\begin{array}{l}2 \\
(33.3)\end{array}$ & $\begin{array}{l}1 \\
(16.7)\end{array}$ & 0 & $\begin{array}{l}5 \\
(83.3)\end{array}$ & $\begin{array}{l}10 \\
(15.9)\end{array}$ & 0 & 0 \\
\hline $\begin{array}{l}\text { Infection } \\
\& \\
\text { infestatio }\end{array}$ & ons & $\begin{array}{l}1 \\
(100)\end{array}$ & 0 & 0 & $\begin{array}{l}1 \\
(16.7)\end{array}$ & 0 & $\begin{array}{l}1 \\
(16.7)\end{array}$ & $\begin{array}{l}1 \\
(16.7)\end{array}$ & 0 & $\begin{array}{l}1 \\
(16.7)\end{array}$ & $\begin{array}{l}5 \\
(7.9)\end{array}$ & 0 & 0 \\
\hline $\begin{array}{l}\text { Musculos } \\
\text { and } \\
\text { con- } \\
\text { nec- } \\
\text { tive } \\
\text { tissue } \\
\text { disorders }\end{array}$ & sleletal & 0 & $\begin{array}{l}1 \\
(20.0)\end{array}$ & 0 & $\begin{array}{l}1 \\
(16.7)\end{array}$ & $\begin{array}{l}1 \\
(20.0)\end{array}$ & 0 & 0 & $\begin{array}{l}1 \\
(16.7)\end{array}$ & $\begin{array}{l}1 \\
(16.7)\end{array}$ & $\begin{array}{l}5 \\
(7.9)\end{array}$ & 0 & 0 \\
\hline $\begin{array}{l}\text { Respirat } \\
\text { tho- } \\
\text { racic } \\
\text { and } \\
\text { medi- } \\
\text { asti- } \\
\text { nal } \\
\text { disorders }\end{array}$ & $\begin{array}{l}\text { ory, } \\
(6.2)\end{array}$ & 0 & 0 & 0 & 0 & 0 & $\begin{array}{l}1 \\
(16.7)\end{array}$ & $\begin{array}{l}1 \\
(16.7)\end{array}$ & $\begin{array}{l}1 \\
(16.7)\end{array}$ & 0 & $\begin{array}{l}4 \\
(6.3)\end{array}$ & 0 & $\begin{array}{l}1 \\
(16 .\end{array}$ \\
\hline $\begin{array}{l}\text { Gastroin } \\
\text { disorders }\end{array}$ & $\begin{array}{l}\text { testinal } \\
\text { ( }(12.5)\end{array}$ & 0 & 0 & 0 & $\begin{array}{l}1 \\
(16.7)\end{array}$ & 0 & 0 & 0 & $\begin{array}{l}1 \\
(16.7)\end{array}$ & 0 & $\begin{array}{l}4 \\
(6.3)\end{array}$ & 0 & 0 \\
\hline $\begin{array}{l}\text { General } \\
\text { disor- } \\
\text { ders } \\
\text { and } \\
\text { ad- } \\
\text { minis- } \\
\text { tra- } \\
\text { tion } \\
\text { site } \\
\text { disorders }\end{array}$ & 0 & 0 & 0 & 0 & $\begin{array}{l}2 \\
(33.3)\end{array}$ & 0 & 0 & 0 & 0 & 0 & $\begin{array}{l}2 \\
(3.2)\end{array}$ & 0 & 0 \\
\hline $\begin{array}{l}\text { Injury, } \\
\text { poi- } \\
\text { soning } \\
\text { and } \\
\text { proce- } \\
\text { dural } \\
\text { complica }\end{array}$ & $\begin{array}{l}1 \\
(6.2) \\
\\
\text { ations }\end{array}$ & 0 & 0 & 0 & 0 & 0 & 0 & $\begin{array}{l}1 \\
(16.7)\end{array}$ & 0 & 0 & $\begin{array}{l}2 \\
(3.2)\end{array}$ & 0 & 0 \\
\hline $\begin{array}{l}\text { Psychiat } \\
\text { disorders }\end{array}$ & & 0 & 0 & 0 & 0 & $\begin{array}{l}1 \\
(20.0)\end{array}$ & 0 & 0 & 0 & 0 & $\begin{array}{l}1 \\
(1.6)\end{array}$ & 0 & 0 \\
\hline
\end{tabular}

IRT: immediate-release tablet; LSF: liquid service formulation

Subjects with [?] 1 adverse event are counted only once per system organ class and preferred term. 
a One subject received $0.1 \mathrm{mg}$ emodepside LSF, which was recorded as a protocol deviation.

Table 9. Treatment-emergent adverse events reported with emodepside and placebo in the multiple ascending dose study, presented by system organ class

\begin{tabular}{|c|c|c|c|c|c|}
\hline & & Emodepside & Emodepside & Emodepside & \\
\hline $\begin{array}{l}\text { System Organ } \\
\text { Class }\end{array}$ & $\begin{array}{l}\text { Placebo } N=6 \\
\text { n }(\%)\end{array}$ & $\begin{array}{l}\text { LSF } 5 \text { mg OD } \\
N=6 \text { n }(\%)^{a}\end{array}$ & $\begin{array}{l}\text { LSF } 10 \mathrm{mg} \text { OD } \\
\mathrm{N}=6 \mathrm{n}(\%)\end{array}$ & $\begin{array}{l}\text { LSF } 10 \mathrm{mg} \\
\text { BID N=6 n } \\
(\%)\end{array}$ & $\begin{array}{l}\text { All subjects } \\
\mathrm{N}=24 \mathrm{n}(\%)\end{array}$ \\
\hline Any TEAE & $4(66.7)$ & $5(83.3)$ & $6(100.0)$ & $6(100)$ & $21(87.5)$ \\
\hline $\begin{array}{l}\text { Infections \& } \\
\text { infestations }\end{array}$ & 0 & $4(66.7)$ & $4(66.7)$ & $1(16.7)$ & $9(37.5)$ \\
\hline Eye disorders & $1(16.7)$ & $3(50.0)$ & $1(16.7)$ & $3(50.0)$ & $8(33.3)$ \\
\hline $\begin{array}{l}\text { Musculoskeletal } \\
\text { and connective } \\
\text { tissue disorders }\end{array}$ & 0 & $2(33.3)$ & $2(33.3)$ & $1(16.7)$ & $5(20.8)$ \\
\hline $\begin{array}{l}\text { Nervous } \\
\text { system } \\
\text { disorders }\end{array}$ & $2(33.3)$ & $2(33.3)$ & 0 & 0 & $4(16.7)$ \\
\hline $\begin{array}{l}\text { Gastrointestinal } \\
\text { disorders }\end{array}$ & $2(33.3)$ & $2(33.3)$ & 0 & 0 & $4(16.7)$ \\
\hline $\begin{array}{l}\text { General } \\
\text { disorders and } \\
\text { administration } \\
\text { site disorders }\end{array}$ & 1 (16.7) & $1(16.7)$ & $1(16.7)$ & $1(16.7)$ & $4(16.7)$ \\
\hline $\begin{array}{l}\text { Psychiatric } \\
\text { disorders }\end{array}$ & 0 & $2(33.3)$ & $1(16.7)$ & 0 & $3(12.5)$ \\
\hline $\begin{array}{l}\text { Skin and } \\
\text { subcutaneous } \\
\text { tissue } \\
\text { disorders }\end{array}$ & 0 & $1(16.7)$ & $1(16.7)$ & 0 & $2(8.3)$ \\
\hline Investigations & 0 & 0 & 0 & $1(16.7)$ & $1(4.2)$ \\
\hline $\begin{array}{l}\text { Immune } \\
\text { system } \\
\text { disorders }\end{array}$ & 0 & 0 & 0 & $1(16.7)$ & $1(4.2)$ \\
\hline $\begin{array}{l}\text { Injury, poisoning } \\
\text { and procedural } \\
\text { complications }\end{array}$ & 0 & 0 & 0 & 1 (16.7) & $1(4.2)$ \\
\hline $\begin{array}{l}\text { Metabolism } \\
\text { and nutrition } \\
\text { disorders }\end{array}$ & 0 & 0 & $1(16.7)$ & 0 & $1(4.2)$ \\
\hline $\begin{array}{l}\text { Respiratory, } \\
\text { thoracic and } \\
\text { mediastinal } \\
\text { disorders }\end{array}$ & 0 & $1(16.7)$ & 0 & 0 & $1(4.2)$ \\
\hline $\begin{array}{l}\text { Surgical and } \\
\text { medicinal } \\
\text { procedures }\end{array}$ & 0 & 0 & $1(16.7)$ & 0 & $1(4.2)$ \\
\hline
\end{tabular}

LSF: liquid service formulation; OD: once daily; BID: bis in diem (twice daily) 
Subjects with [?] 1 adverse event are counted only once per system organ class and preferred term.

Table 10. Treatment-emergent adverse events reported with emodepside in the relative bioavailability study, presented by system organ class

\begin{tabular}{|c|c|c|c|c|c|c|c|c|}
\hline & Part 1 & Part 1 & Part 1 & Part 1 & Part 1 & Part 1 & Part 2 & Part 2 \\
\hline & $\begin{array}{l}\text { LSF } 5 \\
\text { mg }\end{array}$ & $\begin{array}{l}\text { ASD } \\
\text { tablet } \\
5 \mathrm{mg}\end{array}$ & $\begin{array}{l}\text { ASD } \\
\text { tablet } \\
5 \mathrm{mg}\end{array}$ & $\begin{array}{l}\text { ASD } \\
\text { tablet } \\
5 \mathrm{mg}\end{array}$ & $\begin{array}{l}\text { ASD } \\
\text { tablet } \\
5 \mathrm{mg}\end{array}$ & & $\begin{array}{l}\text { ASD } \\
\text { tablet } \\
10 \mathrm{mg}\end{array}$ & $\begin{array}{l}\text { ASD } \\
\text { tablet } \\
10 \mathrm{mg}\end{array}$ \\
\hline System & Fasting & GR & GS & GR fed & GS fed & All & GR & GS \\
\hline Organ & $\mathrm{N}=11$ & fasting & fasting & $\mathrm{N}=12 \mathrm{n}$ & $\mathrm{N}=11 \mathrm{n}$ & subjects & fasting & fasting \\
\hline Class & n (\%) & $\begin{array}{l}N=11 n \\
(\%)^{a}\end{array}$ & $\begin{array}{l}N=10 \mathrm{n} \\
(\%)\end{array}$ & $(\%)$ & $(\%)$ & $\begin{array}{l}N=55 \mathrm{n} \\
(\%)\end{array}$ & $\begin{array}{l}N=12 \mathrm{n} \\
(\%)\end{array}$ & $\begin{array}{l}\mathrm{N}=10 \mathrm{n} \\
(\%)\end{array}$ \\
\hline Any & 3 & 5 & 2 & $1(8.3)$ & 5 & 16 & 0 & 4 \\
\hline TEAE & $(27.3)$ & $(45.5)$ & $(20.0)$ & & $(45.5)$ & $(29.1)$ & & $(40.0)$ \\
\hline $\begin{array}{l}\text { Nervous } \\
\text { system } \\
\text { disorders }\end{array}$ & $1(9.1)$ & $\begin{array}{l}2 \\
(18.2)\end{array}$ & $\begin{array}{l}1 \\
(10.0)\end{array}$ & $1(8.3)$ & $\begin{array}{l}3 \\
(27.3)\end{array}$ & $\begin{array}{l}8 \\
(14.5)\end{array}$ & 0 & $\begin{array}{l}2 \\
(20.0)\end{array}$ \\
\hline $\begin{array}{l}\text { Gastrointesti } \\
\text { disorders }\end{array}$ & inlat(9.1) & $1(9.1)$ & $\begin{array}{l}1 \\
(10.0)\end{array}$ & 0 & $1(9.1)$ & $4(7.3)$ & 0 & $\begin{array}{l}1 \\
(10.0)\end{array}$ \\
\hline $\begin{array}{l}\text { Infections } \\
\& \\
\text { infestations }\end{array}$ & 0 & $1(9.1)$ & $\begin{array}{l}1 \\
(10.0)\end{array}$ & 0 & $1(9.1)$ & $3(5.5)$ & 0 & 0 \\
\hline $\begin{array}{l}\text { Eye } \\
\text { disorders }\end{array}$ & 0 & 0 & $\begin{array}{l}1 \\
(10.0)\end{array}$ & 0 & 0 & $1(1.8)$ & 0 & $\begin{array}{l}1 \\
(10.0)\end{array}$ \\
\hline $\begin{array}{l}\text { General } \\
\text { disorders } \\
\text { and } \\
\text { adminis- } \\
\text { tration } \\
\text { site } \\
\text { disorders }\end{array}$ & $1(9.1)$ & 0 & 0 & 0 & 0 & $1(1.8)$ & 0 & $1(10.0)$ \\
\hline $\begin{array}{l}\text { Skin } \\
\text { and } \\
\text { subcu- } \\
\text { ta- } \\
\text { neous } \\
\text { tissue } \\
\text { disorders }\end{array}$ & 0 & $1(9.1)$ & 0 & 0 & 0 & $1(1.8)$ & 0 & 0 \\
\hline
\end{tabular}

ASD: amorphous solid dispersion; GR: gastroresistant; GS: gastrosoluble; LSF: liquid service formulation Subjects with [?] 1 adverse event are counted only once per system organ class and preferred term.

k) Figures

Hosted file

image1.emf available at https://authorea.com/users/354289/articles/477903-safetypharmacokinetics-relative-bioavailability-and-dose-linearity-of-four-formulations-ofemodepside-in-healthy-male-subjects

Figure 1. Geometric mean plasma emodepside concentration versus time profiles after single 
oral administration of ascending doses from $1 \mathrm{mg}$ to $40 \mathrm{mg}$ as LSF or of $5 \mathrm{mg}$ and $20 \mathrm{mg}$ IRT LLOQ: lower limit of quantitation; LSF: Liquid service formulation; IRT: immediate release tablet

Error bars represent geometric standard deviation (SD)

Figure 2. Geometric mean plasma emodepside concentration versus time profiles after multiple oral administration of ascending doses of $5 \mathrm{mg}$ OD, $10 \mathrm{mg}$ OD or $10 \mathrm{mg}$ BID as LSF

Panel A - Geometric mean plasma emodepside concentration versus time profiles up to $24 \mathrm{~h}$ after dosing on Day 0

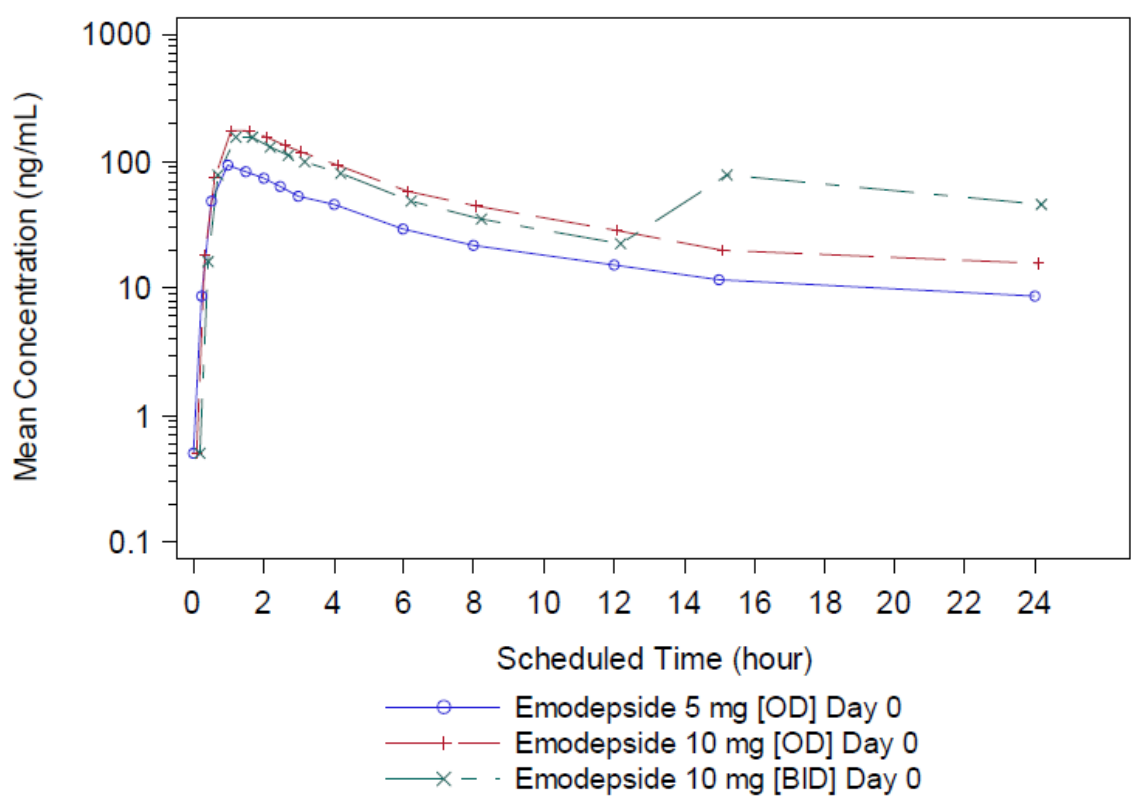

Panel B - Geometric mean plasma emodepside concentration versus time profiles up to $12 \mathrm{~h}$ after dosing on Day 9 


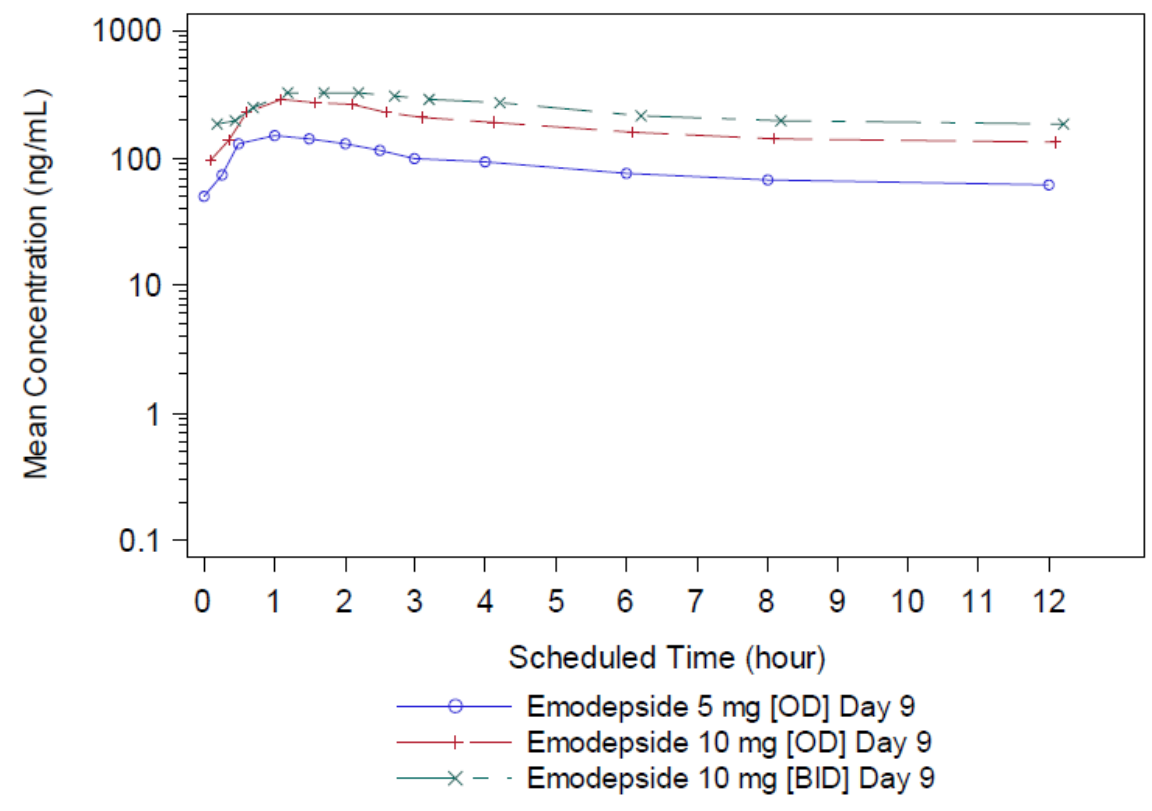

Panel C - Geometric mean plasma emodepside concentration versus time profiles up to $528 \mathrm{~h}$ after dosing on Day 9

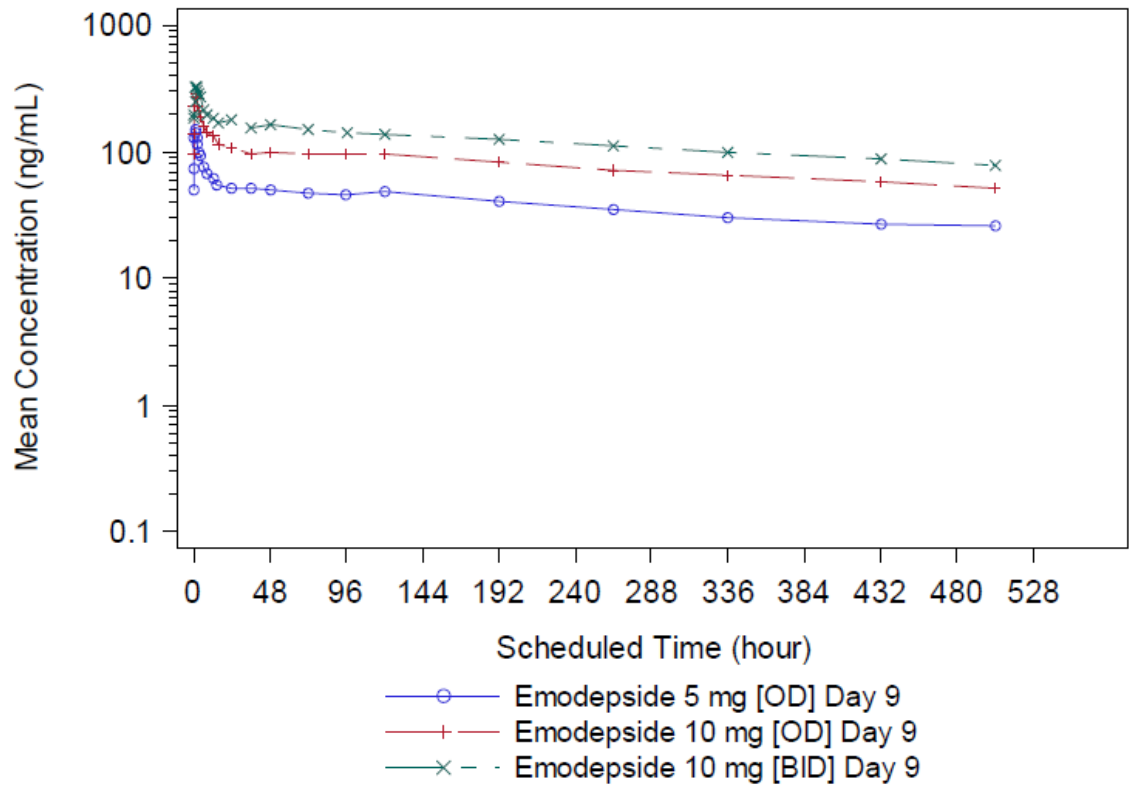

Figure 3. Geometric mean plasma emodepside concentration versus time profiles up to $12 \mathrm{~h}$ after single oral doses of $5 \mathrm{mg}$ (upper panel) or $10 \mathrm{mg}$ (lower panel)

Hosted file

image5.emf available at https://authorea.com/users/354289/articles/477903-safetypharmacokinetics-relative-bioavailability-and-dose-linearity-of-four-formulations-ofemodepside-in-healthy-male-subjects 


\section{Hosted file}

image6.emf available at https://authorea.com/users/354289/articles/477903-safetypharmacokinetics-relative-bioavailability-and-dose-linearity-of-four-formulations-ofemodepside-in-healthy-male-subjects

ASD: amorphous solid dispersion; LSF: liquid service formulation

Error bars represent geometric standard deviation (SD) 